Maciejczyk-Bujnowicz I. (2016). Capital Flows in European Union on the Basis of International Investment Position - Selected Aspects. Copernican Journal of Finance \& Accounting, 5(1), 157-172. http://dx.doi.org/10.12775/CJFA.2016.009

\author{
Iwona Maciejczyk-Bujnowicz* \\ University of Lodz
}

\title{
CAPITAL FLOWS IN EUROPEAN UNION ON THE BASIS OF INTERNATIONAL INVESTMENT POSITION - SELECTED ASPECTS**
}

Keywords: International Investment Position, capital flows, financial crisis, euro area, foreign direct investment, financial integration.

JEL Classification: F5, F3, F36.

Abstract: The paper aims at assessing the changes in flows of selected forms of capital under deepening financial integration in the European Union. EU Member States are divided into two groups: members of the euro area and those outside of it. The analysis coincides with the establishing of the EU monetary union and covers the turn and early 21st century. Research method applied in this particular study includes the overview of theoretical concepts, literature review and a comparative statistical analysis based on statistical data. Analyses of selected data revealed significant differences between developed and developing countries when it comes to various forms of net capital and its relation to the GDP based on the International Investment Position. Moreover, we evaluated the International Investment Position of Poland against the backdrop of selected countries of Central and Eastern Europe and the eurozone members.

Date of submission: January 10, 2016; date of acceptance: May 11, 2016.

* Contact information: iwonabujnowicz@uni.lodz.pl, Department of International Economic Relations, Faculty of Economics and Sociology, University of Lodz, ul. POW 3/5 90-255 Łódź, Poland, phone: +48503454990 .

** Paper financed under the research grant of the National Science Centre No.: UMO-2013/09/B/HS4/01329 "Impact of Capital Imports upon Economic Growth". 


\section{INTRODUCTION}

The paper tries to evaluate the changes in capital flows under the deepening financial and trade integration in the EU. We analysed net International Investment Position of the EU countries. The countries were divided into two groups: members of the eurozone and Member States outside of it. The analysis coincides with the establishing of the monetary union in the EU and covers the period 1998-2011, and 2003-13 for Poland. Moreover, we conducted comparative analysis of selected IIP values for Poland against the backdrop of countries of Central and Eastern Europe and the members of the euro area. We need to stress that the stream of payments resulting from increased trade among countries caused, inter alia, by increased GDP was largely directed not only to the real sector but increasingly to the financial sector. The two sectors: financial and real one started to go apart. This specific asymmetry of trade flows and the flows of payments dictated changes in the balance of payments of individual economies. National financial systems became resistant to the controls and operations of monetary and fiscal authorities. Free inflow and outflow of capital, in particular loans, intensified financial intermediation. Increases in the volume of transborder financial flows, combined with limited autonomy of domestic macroeconomic policy and monetary authorities of a deficit country getting quickly indebted abroad, revealed the inability to effectively counteract overappreciation of the domestic currency and significant reduction of domestic interest rates (Najlepszy, Sobański 2010). Besides, according to J. Bilski too deep reduction of interest rates may largely reduce the inflow of portfolio capital and initiate depreciation, which may threaten the financing of current account deficit from foreign sources (Bilski 2006). Croosborder capital flows broke up when the crisis began in 2008, which was also reflected in global trade turnover (Sula, Willet 2009). Developed members of the eurozone, especially those, which made their growth dependent upon the inflow of foreign capital, suffered the most from the lack of capital. In some countries, specifically in peripheral ones, credit boom in the market of consumer and mortgage loans caused, inter alia, by low interest rates, contributed to the speculative bubble in the real estate market. As a result of rapid increase in the risk of investing in foreign financial markets, capital, in particular portfolio capital, was flowing out of individual countries. From the viewpoint of the stability, the system is the most sensitive to developments in global markets. The latest crisis of 2008-11 
revealed weaknesses of progressing financial integration of the banking system not only in the United States but also in the EU.

Literature provides arguments that lay grounds for the stability of external balance of a country. Many studies on the instability of external balance demonstrate that global capital flows may be the critical variable that destabilizes external balance of a particular country. Capital flows offer possibilities and ways of balancing international trade turnover of states. Moreover, capital flows are influenced by balance of payment forecasts and thresholds specifying safe level of future macroeconomic equilibrium. Too quick and too wide, in relation to the expected, inflow of capital may deteriorate the net investment position ${ }^{1}$ of a country and the terms of foreign debt servicing (Najlepszy, Sobański 2010).

\section{RESEARCH METHODOLOGY AND PROCESS RESEARCH}

Classical economy ${ }^{2}$ is considered the first strand in the theory of economics, which looks at processes that take place among economies in a comprehensive way. From theoretical point of view, an ideal situation is the one when the balance of payment is zero. In modern times it is hard to find an example of economy where domestic savings equal pending investment projects. That is the case of the so called "closed economy". In open economies freely moving capital enables to finance investment when there is not enough capital in the home market. As a result, we have surpluses or shortages in the balance of payments. Moreover, under the absence of external balance it is hard to arrive at internal balance, both in the real and in the financial sectors. The model of general economic stability IS-LM supplements Keynes's theory (Hicks 1937). It describes the behaviour of the real and financial sectors in the internal market, for which it was vastly criticised. The IS-LM-BP model expanded by MundellFleming shows the balance achieved simultaneously in internal and external

${ }^{1}$ International Investment Position (IIP) is a statistical statement compiled at the end of a given period, which outlines foreign assets and liabilities of residents vis-a-vis non-residents. The difference between foreign assets and liabilities is the Net International Investment Position, which informs whether a country is a net creditor or net debtor vis-a-vis other countries.

2 The strand is represented by: Smith, A 1776, An Inquiry into the Nature and Causes of the Wealth of Nations, marks the beginning of classical economics, Ricardo, D 1817, On the Principles of Political Economy and Taxation, Mill, JS 1865, Principles of Political Economics. 
markets. In this approach when there is disequilibrium in the balance of payment, restrictions may be imposed upon such capital flows, which threaten the stability of the balance of payments (Mundell 1968). Pursuant to the assumptions of the IS-LM-BP model, taking account of the assumptions of the Keynes's theory, the degree of liberalisation of capital flows (complete, partial or no liberalisation) with floating exchange rate enable effective monetary policy. On the other hand, if we adopt a fixed exchange rate regime, monetary policy is ineffective. If, however, for the fixed exchange rate model we pursue an expansive fiscal policy, its effectiveness will be the highest under partial liberalisation of capital flows. The dichotomy of using many solutions was applied in the idea of „Impossible Trinity”. It means it is impossible to have all three of the following at the same time: stabilisation of the exchange rate, independent monetary policy, and full liberalisation of capital flows. Monetarism emerged after World War II. The main representative of the monetarist theory is Friedman (1957), who spoke in favour of economic liberalism. He criticised theoretical assumptions of the far-reaching Keynes interventionism. After the collapse of the Bretton Woods system the volume of international flows increased. Individual countries started eliminating barriers to it. Additionally, in 1990 Lucas (Lucas 1990) published an article, in which he highlighted certain relationship that was termed the Lucas paradox in literature. He noticed that capital, contrary to theoretical assumptions, flows from poor to rich countries, not the reverse. Thus, he challenged conclusions of the neoclassical theory, according to which we expect capital to flow to poor countries from rich countries better equipped in capital.

Since the 1970s and 1980s in developed countries we have observed increasing share of liabilities in GDP (Total Liabilities/GDP). As of the beginning of the 1990 s until early $21^{\text {st }}$ century the share of equity capital in GDP dynamically increased $(E Q I=(F D I+$ Portfolio Equity $) / G D P)$. Between the 1970s and 2004 the EQI ratio increased by ca. 40 p.p. (from ca. $5 \%$ of GDP to ca. $45 \%$ GDP) in developed countries while in developing countries the increase reached ca. 20 p.p. (from ca. 10\% GDP to ca. 30\% GDP). Interestingly, between the 1970s and mid1980s developing economies covered by the study reported decreased (by ca. $50 \%$ ) share of equity in total capital structure (Equity/Total Liabilities) from ca. $35 \%$ to ca. $16-18 \%$ on average. In rich countries the drop was slightly more moderate (ca. 10 p.p.) and represented ca. $25 \%$ of liabilities. Since the 1990 s both groups of countries demonstrated high rate of growth of equity in capital structure. In rich countries the increase of equity in liabilities reached on av- 
erage ca. $40 \%$ in 2000 while later on its proportion decreased to ca. $30 \%$, contrary to the rest of countries, where its share increased to ca. $50 \%$ in total liabilities. Lane and Milesi-Ferretti (2000) reviewed literature concerning the essence and structure of external investment position of countries. Based on that they selected potential determinants of the financial structure of the balance of payments in developed and developing countries. Special attention was paid to the relation between debt structure and equity (FDI + Portfolio Capital). The analysis of results obtained from the regression function allowed to formulate interesting conclusions. One of them says that relatively bigger countries with a developed financial market and open to trade have externally diversified financial structure (external diversification). The group of developing countries is dominated by diversified structure of liabilities. Both developed and developing countries from the group of high GDP per capita enjoy higher levels of assets and liabilities and usually are bigger creditors than smaller countries. According to the Authors (Lane \& Milesi-Ferretti 2000) openness to trade favours capital flows of all types, however, equity flows, in particular FDI, slightly dominate debt. Summing up, we may say that the size of the country, economic development and the development of capital market encourage the inflow of equity capital. Other researchers (Faria et al. 2006), as a result of horizontal and time-based analysis of economies, selected factors decisive for the structure of liabilities of IIP in high-income and other countries. Rich countries have a much higher share of liabilities in the GDP (in 2004 they exceeded 140\% share of liabilities in the GDP) compared to other countries, for which analysed ratio reached ca. $60 \%$ GDP over the same period. Moreover, the increased share of equity in total liabilities of the balance of payments positively correlates with the quality of institutional changes in researched countries. It was also observed that bigger countries have relatively smaller share of foreign liabilities and higher share of portfolio capital in total liabilities. Horizontal analysis for 2004 revealed positive correlation between equity and bigger openness to trade. Lane and Milesi-Ferretti (2006), based on data originating from 145 countries from the period 1970-2004 conducted a synthetic analysis of data and results of calculations. Their attention was paid to the structure of assets and liabilities of the IIP and to the attempt to identify trends in external financial structure of these countries. That results obtained for developed and developing countries are close. There was a 7 -fold increase in the ratio representing the level of international financial integration, from ca. 45\% GDP in 1970 to over $300 \%$ GDP in 2004. In developing countries the 1990s were the years 
of strong integration in equity capital both in relation to GDP and to trade. Obtained results also demonstrated that at the turn of the centuries there were substantial changes in external investment position of analysed countries. Developed countries reported increases in both assets and liabilities in relation to GDP, in particular when it comes to net debtors (e.g., United States, Australia, Spain) and creditors (Japan, Switzerland). In summary, under progressing financial globalisation we observed significant changes in the structure of the balance of payments and international investment positions of analysed countries. Asian and Middle East countries recorded dynamic increase in financial surpluses. The rest of developing countries experienced considerable increase in the share of equity to total liabilities and strong accumulation of foreign exchange reserves.

At the turn of the 20th and 21st centuries significant changes took place in external investment position in the global economy. Developing countries in Asia and in the Middle East improved their external investment positions, while European developing countries experienced changes in capital structure. Countries regarded as developed strengthened their external investment position to GDP due to relatively higher share of liabilities in the IIP structure (Australia, Spain, United States) and relatively higher share of assets in IIP structure (Japan, Switzerland). When it comes to financial integration of developing countries, we may say that its scale is smaller than in developed countries. That is especially true of low level of financial integration with respect to debt. Further liberalisation of capital flows in these countries and further advances in the development of national financial markets may impact progress in further international financial integration. Lane and Milesi-Ferretti (2006) conducted the analysis of statistical external capital structure of IIP liabilities in developed and developing countries. The study analysed and compared the share of equity capital in total liabilities (FDI+Portfolio Equity/TL). In the 1980s and 1990 s both groups of countries exhibited clear increase of equity capital in total liabilities. Over the period 2000-02 its share dropped in favour of debt. In 2004 in developed countries equity reached $36 \%$ of total liabilities. In developing countries its share was ca. $50 \%$ of total assets and ca. $75 \%$ accounted for foreign direct investment. Besides, in developing economies dynamic accumulation of official reserves was observed. The ratio indicating the share of official reserves in total liabilities (debt) increased from 29\% in 1998 to $64 \%$ in 2004. Changes in the structure of external investment position of countries improved, also the investment position of developing countries, due to the in- 
crease in the share of equity and foreign exchange reserves in total liabilities. Lane and Milesi-Ferretti (2001) based on horizontal and time studies on the sample of 67 countries over the period 1970-1998 realised that GDP per capita, public debt and demographic variables have the biggest impact upon the directions in international trade in assets. Prices of assets traded worldwide are determined by foreign net investment position, which, in turn, exerts significant impact upon the performance of long-term real exchange rate. Gruić (2013) made an attempt to identify the determinants of the IIP of selected countries in the light of progressing financial globalisation. Quarterly data cover the period from the 4th quarter of 1997 until the $2^{\text {nd }}$ quarter of 2004. Analyses were conducted for EU Member States, which do not belong to the euro area: the Czech Republic, Hungary, Poland, Slovakia, Slovenia, Bulgaria, Croatia, and Romania. In conclusion Gruić (2013) states that assets and liabilities depend on both domestic and foreign factors, which include: openness to trade, size of the country, capital market development, and degree of financial liberalisation. On top of that, deeper integration measured with the equity ( $E Q I)$ over the studied period can be explained by relatively high share of State-owned enterprises privatised step by step, which encouraged foreign investors to invest in equity within the framework of both FDI and portfolio capital. Catao and Milesi-Ferretti (2013) attempted to identify the determinants of financial crises paying special attention to the role of foreign liabilities and their structure. The period of the study covers the years 1970-2011 and the study concerns 70 countries including 41 developing ones. The authors who used Shin's model (Shin 2012) noticed that the risk of crisis in a given economy rapidly increases when net foreign liabilities exceed 50\% of GDP (NFL/GDP) oscillating between 50-60\% GDP and when the NFL/GDP ratio increases by 20 p.p. above the historic average level for a given country. As a result of the study they noticed that the likelihood of financial crisis increases when the debt to equity ratio in external liabilities of the country relatively increases. The scenario is especially realistic in countries where the share of net debt in liabilities exceeds ca. 35\% GDP. The risk of crisis is lower when the share of net FDI in the capital structure (FDI/TL) increases. The observation is in line with the results of studies conducted by Hausmann and Fernandez-Arias (2001), and Borensztein, De Gregorio \& Lee (1998), which demonstrated positive impact of relatively increasing share of FDI in IIP liabilities of a given country. The higher it is, the more stable and safe the country in the eyes of potential investors. The case of foreign exchange reserves is similar. If their share in foreign assets is relatively high, their impor- 
tance as a preventive measure protecting against the risk of crisis is higher. When it comes to the impact of portfolio equity upon the risk of crisis, results of studies are inconclusive. Current account deficit oscillating around 4\% of GDP is the variable playing the major role in the prediction of crisis in most studied specifications. In general terms, as demonstrated by the decomposition of external net investment position of analysed countries into net equity and net debt, net debt liabilities is the most relevant determinant of net external investment position, which importantly affects the risk of crisis.

Obstfeld and Taylor (2002) and Milessi-Ferretti (2003) constructed a simple measure used to estimate the degree of international investment integration of a given country $(I F I=(F A+F L) / G D P)$. Results obtained from calculations enabled to initially assess the degree of integration. Generally speaking, the higher the ratio, the deeper international financial integration of a given country. EQI ratio $(E Q I=(E Q A+E Q L) / G D P)$ helps evaluate financial integration against equity of a given country with the rest of the world. Like the previous ratio, the higher it is, the deeper financial integration measured with the equity to GDP ratio. By analogy, comparisons were made using the trade integration ratio (total exports and imports/GDP). Below we present statistical analysis of data and try to assess the relationships between international financial integration and financial openness of Poland and selected Central and East European Countries (CEECs). Among the CEECs we focused on: Bulgaria, Croatia, the Czech Republic, Lithuania, Poland, Romania, and Hungary. Besides, we analysed Poland's integration with two groups of countries: members of the euro area (EA) and EU Member States outside of the eurozone (nEA). Euro area consists of 18 economies. The United Kingdom, Denmark and Sweden were not included in the analysis. Below, we can see the average for the above mentioned countries for the period from 2004 till 2011. OX axis gives average openness to trade over the period 2004-2011 while OY axis represents average financial integration.

We may note that the euro area countries compared to non-euro countries remain at opposite extremes. While in the single currency countries (EA) financial integration was on average 3.23 over the years 2004-11, in CEECs (nEA) the ratio amounted to 1.86 . Hungary was the only exception, as their financial integration was on average 3.80 with openness to trade ratio of 1.55 . The degree of financial integration of the rest of EU Member States outside of the euro area ranged between 1.0 and 2.0. Interestingly, the openness ratio for Croatia was 0.88 , for Poland 0.82 , and for Romania 0.76 . 
Figure 1. International financial integration and trade integration of the EU

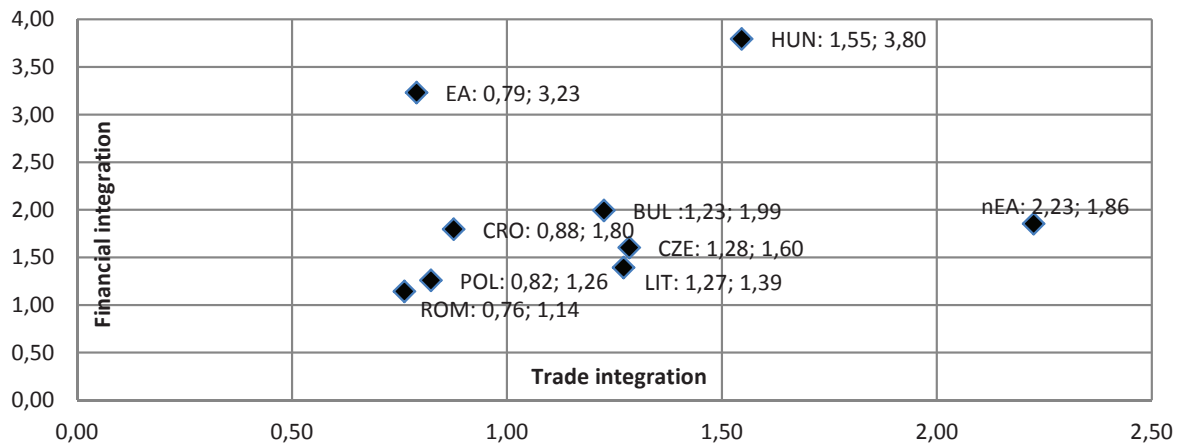

S o u r c e : author's estimates based on Eurostat and IMF data.

Many interesting conclusions can be drawn from the analysis of IIP structure of the eurozone countries and the CEECs outside of the euro area. Changes that took place over recent 14 years concern individual components of IIP liabilities.

Table 1. Net IIP to GDP (\%) of the euro area countries (EA) and CEECs (nEA)

\begin{tabular}{|c|c|c|c|c|c|c|c|c|c|c|c|c|c|c|}
\hline & 1998 & 1999 & 2000 & 2001 & 2002 & 2003 & 2004 & 2005 & 2006 & 2007 & 2008 & 2009 & 2010 & 2011 \\
\hline \multicolumn{15}{|c|}{ Net Foreign Assets/GDP } \\
\hline$n E A$ & $-0,28$ & $-0,33$ & $-0,34$ & $-0,31$ & $-0,36$ & $-0,41$ & $-0,48$ & $-0,46$ & $-0,61$ & $-0,71$ & $-0,64$ & $-0,82$ & $-0,78$ & $-0,67$ \\
\hline EA & $-0,10$ & $-0,07$ & $-0,08$ & $-0,07$ & $-0,12$ & $-0,13$ & $-0,13$ & $-0,10$ & $-0,14$ & $-0,17$ & $-0,18$ & $-0,21$ & $-0,18$ & $-0,18$ \\
\hline \multicolumn{15}{|c|}{ Foreign Direct Investments net/GDP } \\
\hline$n E A$ & $-0,17$ & $-0,21$ & $-0,25$ & $-0,27$ & $-0,31$ & $-0,33$ & $-0,38$ & $-0,34$ & $-0,42$ & $-0,45$ & $-0,36$ & $-0,47$ & $-0,46$ & $-0,38$ \\
\hline EA & 0,01 & 0,05 & 0,05 & 0,06 & 0,03 & 0,01 & 0,01 & 0,04 & 0,06 & 0,07 & 0,07 & 0,10 & 0,11 & 0,12 \\
\hline \multicolumn{15}{|c|}{ Portfolio Investments net/GDP } \\
\hline nEA & $-0,11$ & $-0,12$ & $-0,11$ & $-0,11$ & $-0,11$ & $-0,13$ & $-0,17$ & $-0,16$ & $-0,17$ & $-0,15$ & $-0,10$ & $-0,15$ & $-0,17$ & $-0,16$ \\
\hline EA & $-0,10$ & $-0,13$ & $-0,12$ & $-0,12$ & $-0,14$ & $-0,14$ & $-0,14$ & $-0,14$ & $-0,20$ & $-0,23$ & $-0,22$ & $-0,29$ & $-0,28$ & $-0,28$ \\
\hline \multicolumn{15}{|c|}{ Other Investments net/GDP } \\
\hline nEA & $-0,14$ & $-0,14$ & $-0,14$ & $-0,09$ & $-0,13$ & $-0,17$ & $-0,15$ & $-0,13$ & $-0,16$ & $-0,21$ & $-0,24$ & $-0,33$ & $-0,31$ & $-0,28$ \\
\hline EA & 0,00 & $-0,02$ & $-0,06$ & $-0,05$ & $-0,04$ & $-0,03$ & $-0,02$ & $-0,02$ & $-0,02$ & $-0,02$ & $-0,05$ & $-0,04$ & $-0,04$ & $-0,03$ \\
\hline
\end{tabular}

S o u r c e : author's estimates based on IMF data. 
Based on statistical data for net foreign assets of selected CEECs (nEA) and eurozone members we may conclude that between 1998 and 2011 negative IIP to GDP balance more than doubled. In 1998 NFA amounted to -0.28 GDP while in $2011-0.67$ GDP reaching its maximum of -0.82 GDP in 2009. By analogy, in the euro area countries in 2009 NFA/GDP was almost 4 times lower and accounted for -0.21 GDP. It is worth stressing that FDIs account for the biggest share of negative NFA balance in developing countries. In developed countries the FDI/GDP balance showed positive values in each year covered by the study and amounted from 0.01 GDP in 1998 to 0.12 GDP in 2011. Balance totals of net portfolio capital to GDP in both groups of countries were close since 1998 (nEA: -0.11 GDP; EA: -0.10 GDP) until 2006 (EA: -0.17 GDP; EA: -0.2 GDP). Since 2007 we have observed the divergence of the trajectories for both groups of countries and the dispersion of net balance of PI/GDP across the countries of the euro area (EA: -0.23 GDP) and the CEECs (nEA; -0.15 GDP), which was increasing year to year to reach respectively: EA: -0.28 GDP; nEA: -0.16 GDP in 2011.

Figure 2. Equity in IIP liabilities (EQI/TL) in the euro area and in the CEECs between 1998-2011

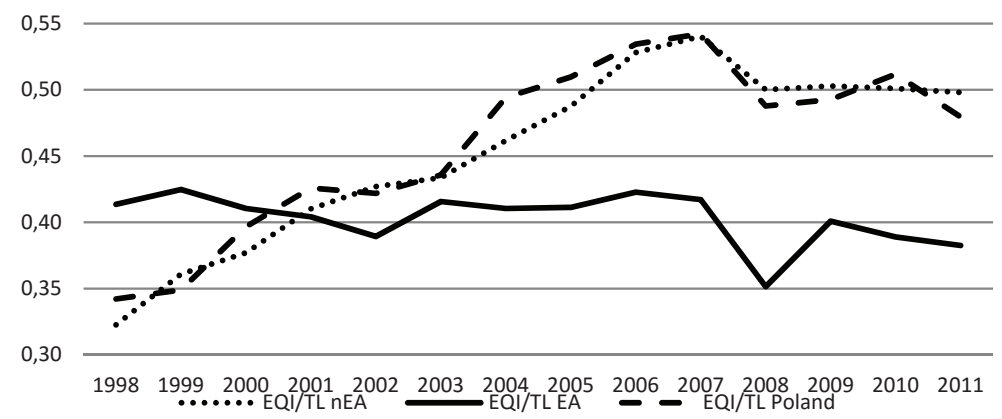

S o u r c e : author's estimates based on NBP and IMF data.

The analysis of data describing the relation of total FDI and short-term capital to TL shows that the changes in their percentage share in the countries of single currency are relatively uniform, with the exception of 2008 when it dropped by 7 p.p. compared to 2007. In selected CEECs countries over the decade from 1998 to 2007 this category of capital increased by 20 p.p., which may evidence positive perception of political and economic perspectives of this group of countries. Since 2004 the difference to the countries from the euro- 
zone has been ca. 10 p.p. on average. Poland does not differ significantly from the average for the CEECs. The collapse in 2008 in this group of countries was 4 p.p. We should stress that the FDI represents the biggest share of this financial position in total liabilities with the average share in the CEECs of $47.0 \%$ compared to $21.0 \%$ in the eurozone over the period 2004-2011. When analysing data concerning the share of FDI in the capital structure (FDI/EQI) we may note that between 2004 and 2011 the ratio was almost $90 \%$ in the group of selected CEECs while in the eurozone economies it was ca. $52 \%$ of total equity $(E Q I / T L)$. It is illustrated in the figure below.

Figure 3. Share of FDI in equity in the euro area countries and in CEECs in the years 1998-2011

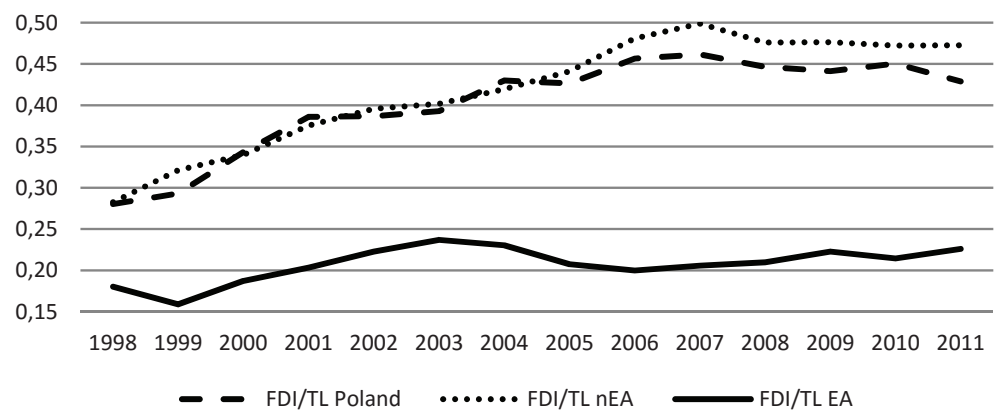

S o u r c e : author's estimates based on NBP and IMF data.

The analysis of the structure of IIP liabilities in countries included in the study can be supplemented with the identification of debt to total liabilities ratio $(D E B T / T L)$. As we can see from the below presented data, average share of debt in total liabilities in the CEECs systematically decreases from 68\% in 1998 to $46 \%$ in 2007 to stabilise finally in the following years around $49 \%$. We need to stress that in the times of crisis of 2007-10 financial markets reported shift from equity investment towards less risky debt securities.

Summing up, over the period 1998-2011 both the euro area countries and the countries which are not its members recorded significant changes in IIP structure. Characteristically, the turning point for the present IIP structure in analysed countries was 2000 . While in the case of equity until 2011 we could clearly see its systematically increasing share in the countries from outside of the euro area, the pattern for debt was reverse. As of 2008 the share of debt in liabilities dynamically decreased from $61.0 \%$ in countries - members of the 
monetary union and approached the share of debt in countries from outside of the eurozone in 2011 reaching 50.0\%.

Figure 4. Share of debt capital in liabilities in euro area countries and in the CEECs in the years 1998-2011 (\%)

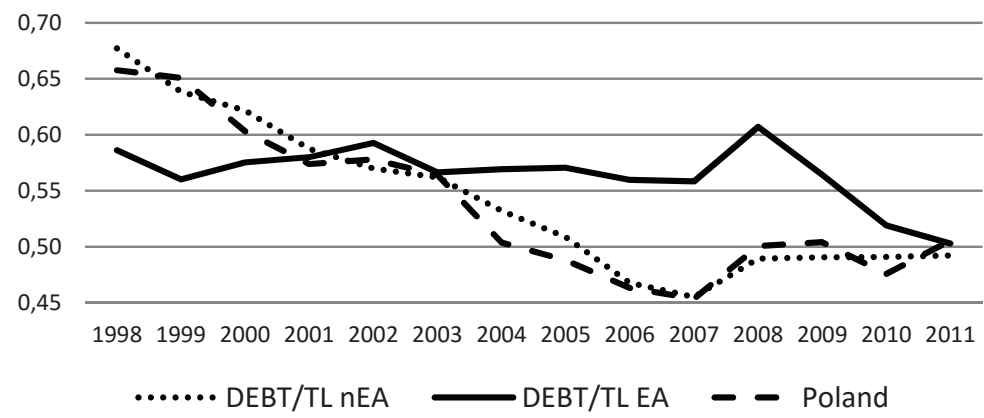

S o u r c e : author's estimates based on NBP and IMF data.

The analysis of Poland's net international investment position and its net components in relation to GDP produces interesting observations. Every year Poland's net IIP to GDP decreases. In 2003 IIP balance was $-41.7 \%$ GDP, while in 2013 it reached $-69.3 \%$ GDP. It means the balance of Poland's financial debt to foreign countries was annually on average $-54.7 \%$ in the period covered by the study. Total liabilities exceeded GDP in 2010 reaching $104.5 \%$ GDP while in 2013 liabilities represented $109.7 \%$ GDP. That may confirm that Poland is perceived as a financially and economically stable country, more and more attractive to foreign investors wishing to invest their long-term capital as net FDIs (-36.9\% GDP in 2013 compared to $-27.0 \%$ GDP in 2004) and net portfolio capital (respectively: $-29.1 \%$ GDP and $-16,1 \%$ GDP).

Data presented in Figure 6 inform us that in Poland net balance of shortterm capital may be on the negative side in 2007-10. Portfolio capital was inflowing into Poland during the latest financial crisis. It means investors decided that financial market in Poland was stable and relatively profitable. In 2008 portfolio capital rapidly flew out of Poland. Over the same period the share of other net foreign investment in GDP increased by 8.3 p.p. compared to 2007. The above observations are complemented with the analysis of decomposed Poland's IIP liability positions both in terms of their structure and dynamics over the period 2003-13. The structure of liabilities of Poland's IIP showed rela- 
Figure 5. International components of Poland's net IIP to GDP over the years 2003-13 (\%)

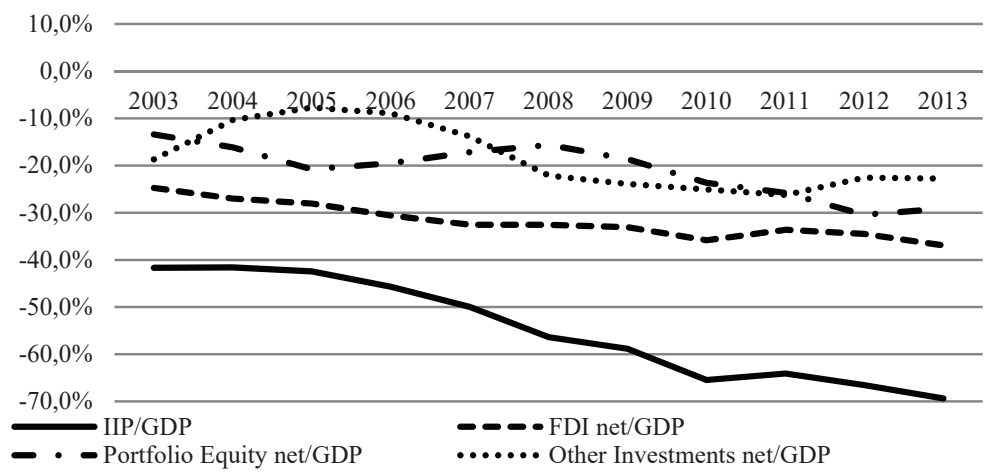

S o u r c e : author's estimates based on NBP data.

tively stable share of its individual components over the period covered by the study. Foreign direct inward investment represented the biggest share and on average accounted for $42.3 \%$. Another significant financial item were portfolio investments (PI), which represented on average ca. $26.7 \%$ in the analysed period. Since 2003 we can observe their systematic increase with the exception of 2008 (20.5\%) when they rapidly shifted away from Poland to reach $29.3 \%$ in total liabilities at the end of 2013. Attention should also be paid to the analysis of data concerning other foreign investments. Their average annual share in IIP liabilities was $30.3 \%$ (it was the highest in $2003-39.3 \%$ and the lowest in 2006 - 25.7\%). Other foreign investments (OI) include granted commercial loans, financial borrowings, cash in current accounts and deposits made in Poland and not included in other categories. The moment Poland joined the European Union, the share of OI was relatively high (over 30\%). Then its share decreased in favour of portfolio investments and FDI. The figure below presents the dynamics of Poland's IIP liabilities where we can see that other investments (OI) rapidly increased to $35 \%$ in 2008 and in the following years on average amounted to ca. $29.5 \%$. The analysis of Poland's IIP is complemented with the structure of gross assets. 
Figure 6. Structure of Poland's IIP assets in the years 2003-13 (\%)

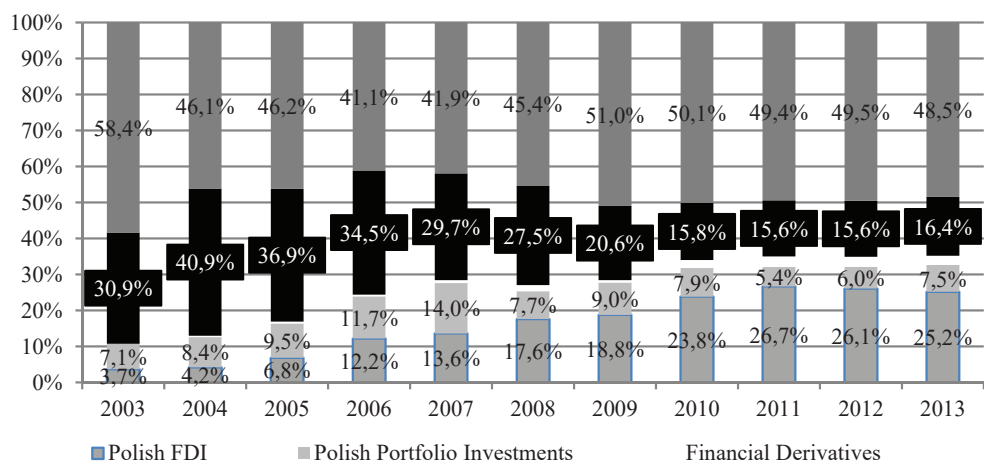

S o u r c e : author's estimates based on NBP data.

The most significant change in the structure of assets of Poland's international investment position that took place over the period of eleven years between 2003 and 2013 was the increase in the share of Polish outward foreign direct investment by ca. 20 p.p. (from $3.7 \%$ in 2003 to $25.2 \%$ of assets in 2013). The share of other foreign investments almost halved from $30.9 \%$ in 2003 to $16.4 \%$ in 2013. Looking at the importance of individual categories in the structure of financial assets of Poland's IIP we can see that portfolio investments outside of the country represented on average $8.6 \%$ annually with the exception of step-wise increases before the crisis, i.e. in 2006-07 when they reached $11.7 \%$ and $14 \%$, respectively.

\section{THE RESULTS AND CONCLUSIONS OF THE RESEARCH PROCESS}

The paper is an overview of basic concepts of economic theories addressing international capital movements. At present, as a result of dynamic changes in the global economy we witness important changes in international capital flows. By taking various forms, these flows reflect the structure of international investment position of individual countries. By analysing the ratios calculated based on collected statistical data we may conclude that there are substantial differences in capital flows and in the structure of IIP between developed and developing countries. The analysis of financial and trade integration of eurozone countries compared to the EU Member States from outside of the single currency area demonstrated that the two groups are at opposite extremes. 
Over the period 2004-11, financial integration in countries using the single currency (EA) was on average twice higher compared to the CEECs (nEA). Moreover, in the period 1998-2011, both eurozone members and countries outside of the single currency area reported considerable changes in the structure of IIP. Portfolio investments of countries-members of the monetary union targeting countries from outside of the area were increasing in importance. The crisis which began in 2008 changed the trends in equity - debt relationship. While in the countries outside of the eurozone the share of debt increased, it decreased for monetary union members. FDIs represent a substantial proportion of equity. In general terms, the value of IIP assets and liabilities increases. Negative balance of financial flows of international investment position to GDP deepened in analysed countries, in particular in the CEECs, which are EU Member States outside of the euro area.

Increasing openness to trade, financial development, financial and trade integration are reflected in capital movements among countries. We need to stress that between 2000 and 2011 Poland got strongly integrated with international market in terms of both financial integration and international integration with respect to equity EQI.

\section{REFERENCES}

Bilski, J. (2006). Międzynarodowy system walutowy, PWE, Warsaw.

Borensztein, E., De Gregorio, J., \& Lee, J.W. (1998). How Does Foreign Direct Investment Affect Economic Growth?. Journal of International Economics, 45, pp. 115-135.

Catao, A.V., \& Milesi-Ferretti, G.M. (2013). External Liabilities and Crises. IMF Working Paper No. 13/113.

Faria A., Lane, P.R., Mauro, P., \& Milesi-Ferretti, G.M. (2006). The Shifting Composition of External Liabilities, IIIS Discussion Paper, No. 190.

Friedman, M. (1957). Theory of the Consumption Function, Princeton University Press, Princeton.

Gruić, B. (2013). Determinants of international investment position, Croatian National Bank, Zagreb.

Hausmann, R., \& Fernandez-Arias, E. (2001). Is Foreign Direct Investment a Safer Form of Financing?. Emerging Markets Review, vol. 2, 1, pp. 34-48, Croatia.

Hicks, J. (1937). Mr Keynes and the "Classics". Suggested Interpretation, Econometrica, No. 5, pp. 147-159.

Jevons, W.S. (1871). The Theory of Political Economy, Macmillan and Co., London.

Keynes, J.M. (1936). The General Theory of Employment, Interest and Money, Macmillan Cambridge University Press, Cambridge. 
Lane, P.R., \& Milesi-Ferretti, G.M. (2000). External Capital Structure: Theory and Evidence, IMF Working Paper, WP/00/152.

Lane, P.R., \& Milesi-Ferretti, G.M. (2001). The External Wealth of Nations: Measures of Foreign Assets and Liabilities for Industrial and Developing Countries. http://www. imf.org/EXTERNAL/PUBS/CAT/longres.cfm?sk\&sk=3258.0 (accessed: 10.11.2011).

Lane, P.R., \& Milesi-Ferretti, G.M. (2003). International financial integration, IMF Staff Papers, Vol. 50 Special Issue, pp. 82-113, Washington.

Lane, P.R., \& Milesi-Ferretti, G.M. (2006). The External Wealth of Nations Mark II: Revised and Extended Estimates of Foreign Assets and Liabilities, 1970-2004, IMF Working Paper, WP/06/69. http://www.imf.org/external/pubs/ft/wp/2006/data/ wp0669.zip (accessed: 10.11.2011).

Lucas, R. (1990). Why Doesn't Capital Flow from Rich to Poor Countries. American Economic Review, No. 80.

Mundell, R.A. (1968). International Economics, The Macmillan Company, New York.

Najlepszy, E., \& Sobański, K. (2010). Niestabilność równowagi zewnętrznej krajów rozwijających się, PWE, Warsaw.

Obstfeld, M., \& Taylor, A. (2002). Globalization and Capital Markets, NBER Working Papers 8846.

Shin, H.S. (2012). Global Banking Glut and Loan Risk Premium. IMF Economic Review, 60 , pp. $155-192$.

Sula, O., \& Willet, T.D. (2009). The reversibility of different types of capital flows to emerging markets, Emerging Market Review, 10.

www.imf.org (accessed: 14.05.2014, 18.05.2014).

www. nbp.pl (accessed: 18.05.2014).

www.stat.gov.pl (accessed: 24.04.2014). 